\title{
Children's false memories: Easier to elicit for a negative than for a neutral event
}

Citation for published version (APA):

Otgaar, H. P., Candel, I. E. L., \& Merckelbach, H. L. G. J. (2008). Children's false memories: Easier to elicit for a negative than for a neutral event. Acta Psychologica, 128(2), 350-354.

https://doi.org/10.1016/j.actpsy.2008.03.009

Document status and date:

Published: 01/01/2008

DOI:

10.1016/j.actpsy.2008.03.009

Document Version:

Publisher's PDF, also known as Version of record

\section{Please check the document version of this publication:}

- A submitted manuscript is the version of the article upon submission and before peer-review. There can be important differences between the submitted version and the official published version of record.

People interested in the research are advised to contact the author for the final version of the publication, or visit the DOI to the publisher's website.

- The final author version and the galley proof are versions of the publication after peer review.

- The final published version features the final layout of the paper including the volume, issue and page numbers.

Link to publication

\footnotetext{
General rights rights.

- You may freely distribute the URL identifying the publication in the public portal. please follow below link for the End User Agreement:

www.umlib.nl/taverne-license

Take down policy

If you believe that this document breaches copyright please contact us at:

repository@maastrichtuniversity.nl

providing details and we will investigate your claim.
}

Copyright and moral rights for the publications made accessible in the public portal are retained by the authors and/or other copyright owners and it is a condition of accessing publications that users recognise and abide by the legal requirements associated with these

- Users may download and print one copy of any publication from the public portal for the purpose of private study or research.

- You may not further distribute the material or use it for any profit-making activity or commercial gain

If the publication is distributed under the terms of Article $25 \mathrm{fa}$ of the Dutch Copyright Act, indicated by the "Taverne" license above, 
Provided for non-commercial research and education use. Not for reproduction, distribution or commercial use.

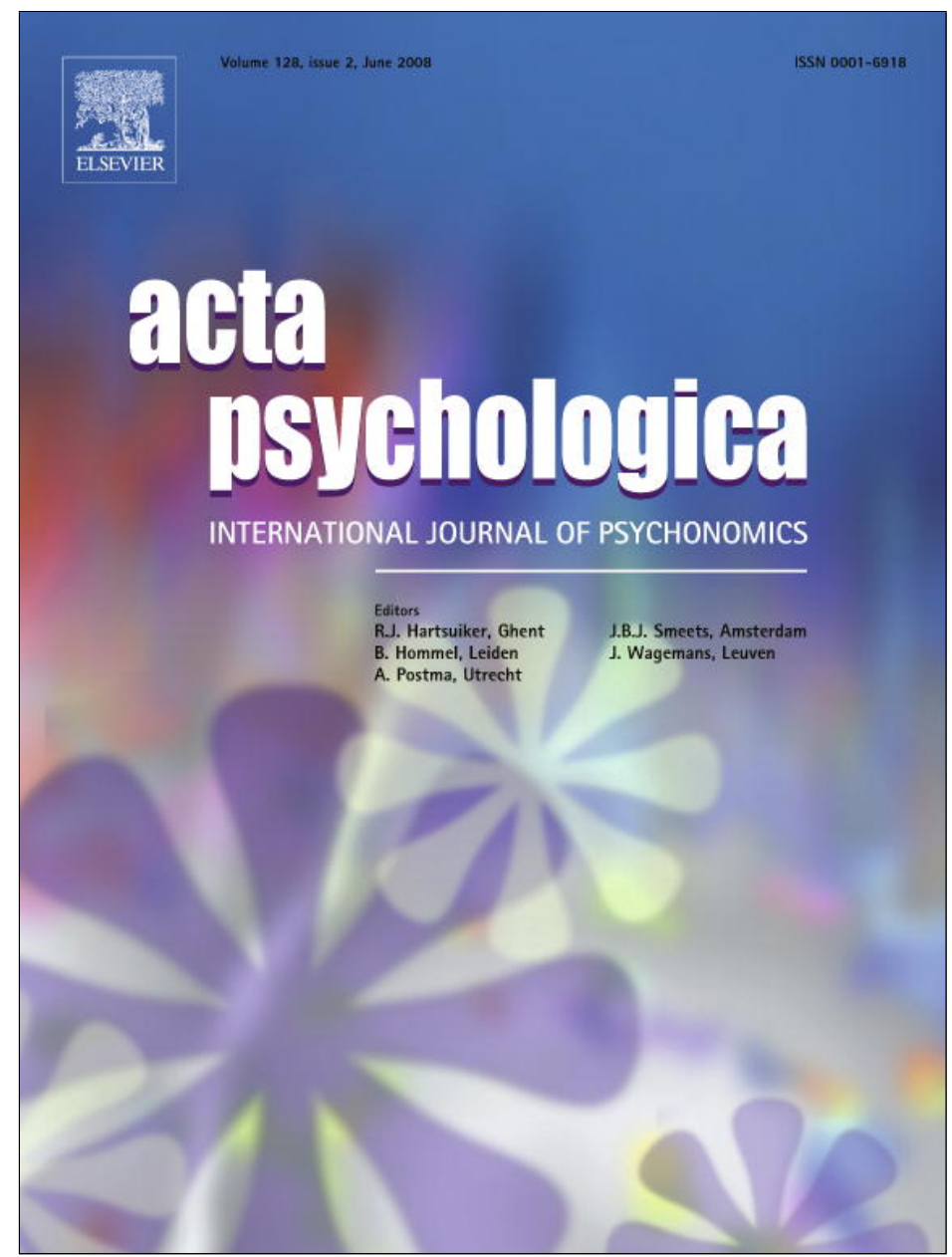

This article appeared in a journal published by Elsevier. The attached copy is furnished to the author for internal non-commercial research and education use, including for instruction at the authors institution and sharing with colleagues.

Other uses, including reproduction and distribution, or selling or licensing copies, or posting to personal, institutional or third party websites are prohibited.

In most cases authors are permitted to post their version of the article (e.g. in Word or Tex form) to their personal website or institutional repository. Authors requiring further information regarding Elsevier's archiving and manuscript policies are encouraged to visit:

http://www.elsevier.com/copyright 


\title{
Children's false memories: Easier to elicit for a negative than for a neutral event
}

\author{
Henry Otgaar*, Ingrid Candel, Harald Merckelbach \\ Maastricht University, Department of Clinical Psychological Science, P.O. Box 616, 6200 MD Maastricht, The Netherlands
}

\section{A R T I C L E I N F O}

\section{Article history:}

Received 18 October 2007

Received in revised form 12 March 2008

Accepted 14 March 2008

Available online 6 May 2008

\section{PsycINFO classification:}

2343

Keywords:

Children

False memories

Valence

Fuzzy trace theory

\begin{abstract}
A B S T R A C T
The present study examined the role of valence in the development of children's implanted false memories. Seventy-six 7-year-old children listened to two true and one false narrative. The false narrative was either neutral ("moving to another classroom") or emotional negative ("being accused by the teacher for copying off your neighbor"). In addition, half of the children were presented with their class photograph while listening to the narratives. During two interviews, children recalled as many details as possible from the true and false events. Results showed that the negative event elicited more false memories than the neutral event. The presentation of a true photograph did not promote the development of false memories.
\end{abstract}

(c) 2008 Elsevier B.V. All rights reserved.

\section{Introduction}

There is an abundance of studies showing that it is relatively easy to elicit false memories, i.e., memories for events that were never experienced, in both adults and children (e.g., Loftus, 2004). Loftus and Pickrell (1995), for example, demonstrated that exposing participants to suggestive narratives promotes the development of false memories. In their study, adults listened to false narratives describing how they were lost in a shopping mall in their childhood. Next, they were instructed to recall everything they could remember about the event. After two interviews, 25\% of the participants $(n=6)$ reported details about the never experienced event. More recently, Wade, Garry, Read, and Lindsay (2002) demonstrated the suggestive power of doctored photographs. In their study, adults were confronted with false photographs depicting themselves during a hot air balloon ride. Over three interviews, they were instructed to recall the event as detailed as possible. Fifty percent $(n=10)$ of the participants eventually concurred with the hot air balloon ride. Despite this straightforward finding, Lindsay, Hagen, Read, Wade, and Garry (2004) questioned the ecological validity of the doctored photograph paradigm. These authors argued that in real life, people rarely encounter doctored photographs. They do, however, look occasionally at true photographs. Some trauma-memory-oriented psychotherapists even use true photographs to help their clients to remember negative events that might have happened to them in their childhood (cf. Poole, Lind-

\footnotetext{
* Corresponding author. Tel.: +31 433884340.

E-mail address: Henry.Otgaar@psychology.unimaas.nl (H. Otgaar).
}

say, Memon, \& Bull, 1995). To examine the effects of true photographs on the development of false memories, Lindsay et al. (2004) presented half of their adult participants with true class photographs that served as a memory cue (photograph condition). All participants were given a false narrative describing that they put "slime" (i.e., a brightly colored gelatinous compound used as a toy) in the teacher's desk when they were a child. Sixty-six percent of the participants $(n=18)$ in the photograph condition developed a false memory for the slime event as compared to $25 \%$ of the participants $(n=5)$ in the no-photograph condition. Lindsay et al. argued that three mechanisms might account for these findings. First, the presentation of the photograph may have strengthened the apparent authenticity of the suggestive narrative. Second, the photographs may have encouraged participants to speculate about the details of the false event. Third, the photograph might have triggered memories of perceptual details (e.g., the teacher's appearance) which then might have become mixed up with imaginative details of the false event.

Like Lindsay et al.'s study, subsequent studies relying on photographs to elicit false memories in adults and children have focused exclusively on the innocuous target events (see for an overview Garry \& Gerrie, 2005). Thus, Wade et al. looked at false memories for a hot air balloon ride, whereas Strange, Sutherland, and Garry (2006) used "drinking a cup of tea with a member of the British royal family" as one of their target events. Legal cases, however, are often about negative events. Therefore, the question arises whether negative events might become the target of false memories as easy as more neutral events. Moreover, no false memory studies using true photographs have concentrated on negative and neutral target events. 
Also, studying the effect of true photographs on memories for negative events is of practical interest, since many trauma-oriented therapies use true photographs as a means to discuss mainly emotional negative events (Poole et al., 1995).

There are only a handful of studies that used the false narrative paradigm to examine whether the valence of false target events affects the development of false memories. These studies have come up with mixed findings. For example, Ceci, Loftus, Leichtman, and Bruck (1994) demonstrated that fewer children assented to a negative false event ("falling off a tricycle and getting stitches in the leg") than to a false positive event ("taking a hot air balloon ride"). On the other hand, Hyman, Husband, and Billings (1995) found that adults who were exposed to false feedback information were equally likely to develop false memories for a negative event ("an overnight hospitalization") and a positive event ("a birthday party with pizza and a clown"). In sum, few studies involving children looked at false memories for a more ecologically valid negative event.

The purpose of the present study was to examine the role that the valence of target events plays in the development of children's false memories. We hypothesized that a negative target event would elicit more false memories than a neutral one. This expectation was based on the recent findings by Talmi and colleagues $(2004,2007)$ that negative emotional information is more highly associated and interrelated in memory than neutral information. Moreover, research suggests that the associative structures that underlie emotional information may be available earlier than neutral information during the development (e.g., Pollack \& Kistler, 2002). Therefore, to the extent that false memories rely heavily on interconnected associative structures (for a review, see Gallo, 2006), we expected that a false narrative about a negative event would elicit more false memories than a false narrative about a neutral event. Our hypothesis that a negative target event would evoke more false memories than a neutral one is also based on the paradoxical negative emotion hypothesis (Porter, Bellhouse, McDougall, ten Brinke, \& Wilson, Submitted for publication; Porter, Taylor, \& ten Brinke, Submitted for publication). According to this hypothesis, negative information will be well recalled over time, but will also be more vulnerable for memory distortion over time than other information. This counterintuitive prediction could be explicated from an evolutionary perspective. That is, although negative events should be well remembered to avoid future dangers, it would be of adaptive value to include relevant information about negative events from other reliable sources (e.g., family, therapists, or researchers). Indeed, recent studies using misinformation and implantation paradigms suggest that negative information increases the susceptibility for false memory formation (e.g., Candel, 2006; Nourkova, Bernstein, \& Loftus, 2004; Porter, Spencer, \& Birt, 2003; Porter, Yuille, \& Lehman, 1999). According to Porter and colleagues (Submitted for publication), the intense (negative) emotion associated with the negative information does not protect memory from false memory effects, but actually increases the likelihood for memory distortion. A subsidiary aim of the present study was to explore whether the presentation of a true photograph would have an effect on false memory rates. To test this, children were presented with either a neutral or a negative false narrative that was either accompanied with a true class photograph or not. Based on Lindsay et al. (2004), we expected that a true photograph would promote false memories for both negative and neutral target events.

\section{Method}

\subsection{Participants}

Seventy-six second grade children $(M=7.62$ years, $S D=0.59$; range 7-9) participated in this study. All children had parental con- sent and received a small present in return for their participation. The study was approved by the standing ethical committee of the Faculty of Psychology, Maastricht University.

\subsection{Materials}

\subsubsection{True narratives}

Children's first grade teachers provided written information about two moderately unique class events that happened to all children a year ago. Event descriptions had to contain information about what the event was, where it took place, and when it took place. These details were integrated in the true narratives. True narratives had a length of approximately three sentences. An example would be "Your teacher from the first grade, miss/mister (name of the teacher), told me that the entire class had to perform a musical. This happened in the summer."

\subsubsection{False narratives}

Our two target events were selected from a pilot study. In that study, 54 children $(M=8.93$ years, $S D=2.14$; range $7-13)$ rated the plausibility and valence of 10 class events (e.g., "seeing the teacher faint") on two different 7-point Smiley scales (anchors: $:=$ implausible/negative, $(-)=$ plausible/positive) with bigger Smileys indicating more plausible/more positive events. Specifically, children were asked how likely the events were to happen for them (i.e., personal plausibility; Scoboria, Mazzoni, Kirsch, \& Relyea, 2004) and how pleasant the events were for them. Children crossed the smiley face that corresponded to their answers. Based on the valence ratings, we selected two events: a neutral event (i.e., "moving to another classroom"; $M=4.28, S D=2.24$ ) and a negative event (i.e., "being accused by the teacher for copying off your neighbor"; $M=1.34, S D=1.27, t(52)=-9.18, p<.001,1$ missing value). These events did not differ in terms of plausibility $\left(M_{\text {neutral }}=6.11\right.$, $S D=1.53, M_{\text {negative }}=5.93, S D=1.78, t(53)<1$, n.s.). Furthermore, a randomly selected group of 18 children $(M=9.44, S D=2.12$, range 7-13) also had to provide script knowledge about the target events. That is, they were instructed to report the typical procedures of our target events. Script knowledge was assessed by using the number of idea units that children reported (Scoboria et al., 2004). For example, when a child reported that all belongings should be brought to the other classroom when the whole class has to move to another classroom, this counted as 1 idea unit. Script knowledge did not significantly differ between the two events $\quad\left(M_{\text {neutral }}=3.33, \quad S D=1.28, \quad M_{\text {negative }}=2.83, \quad S D=1.54\right.$, $t(17)=1.28$, n.s.).

The false narratives were complemented with self-relevant details of the name of the teacher and the grade in which the events allegedly happened. The following descriptions were used as the neutral and negative false narrative, respectively: "Your teacher from the first grade, miss/mister (name of the teacher), told me that your class suddenly had to move from one classroom to another. You had to take all your belongings with you to the other classroom" and "Your teacher from the first grade, miss/mister (name of the teacher), told me that he told you a year ago that you were copying off your neighbor. This shocked you very much, because you were not copying at all." The teachers confirmed that the children had never experienced these events.

\subsubsection{Photographs} grade.

Photographs were authentic class photographs from the first

\subsection{Design and procedure}

The study employed a 2 (photograph: yes vs. no) $\times 2$ (valence: neutral vs. negative) between-subjects design. Children were ran- 
domly assigned to one of the four conditions. They were interviewed individually twice, with one week in between. All interviews were audio taped and transcribed. At the beginning of the first interview, children were told that we were interested in what they could remember of some class events that happened to them a year ago. During each interview, the two true narratives and the false narrative were read aloud. The false narrative was always presented in the third position. The interview procedure was similar to that used by Lindsay et al. (2004). Children were instructed to report freely about the events. In the photograph condition, children were shown a photocopy of their class photograph when the narratives were read to them. If the children were not able to recall an event, they were told that "many people can't recall certain events because they have not thought about them for such a long time. Please concentrate and try again". Children who still did not report any details of the event were involved in guided imagery and context reinstatement techniques. Specifically, children were told to close their eyes and were taken mentally back to the scene of the event. Next, they were asked to think about their feelings, who was with them, and about the time of the year. In such cases, the order of instructions was fixed. Subsequently, children were asked once more to recall the event as detailed as possible. If they were still not able to come up with details, the next narrative was presented.

At the end of the first interview, children were instructed to think about the events every day and if they could remember anything else at the following interview. In addition, children in the class photograph condition received a copy of the photograph. They were instructed to use the photograph as a memory cue when thinking about the events. Moreover, all children were asked not to talk with others about the events. Also, parents were instructed not to discuss the events with their child. Interview 2 was identical to Interview 1. At the end of the second interview, children were debriefed.

\subsection{Scoring}

Responses to the true events were only classified as remembered if a child correctly recalled at least two of the three (what, where, when) event details provided by the teacher. Responses to the false events were scored as false memories if a child stated that it remembered the false events and reported details beyond those mentioned in the false narrative. Likewise, if a child attempted to recall, but did not have any memory of the event, its report was classified as "no false memory". These criteria were adopted from the guidelines formulated by Strange et al. (2006). Two trained, independent raters scored all false reports. Inter-rater agreement for Interview 1 and Interview $2(\kappa)$ was .87 and 1.00 , respectively.

\section{Results}

\subsection{True events}

A total of 152 events had to be recalled. One hundred and twenty-one events (80\%) were remembered at Interview 1 , while at Interview 2, 136 events (89\%) were remembered, $\chi^{2}(1)=25.75$, $p<.001$, Cramer's $V=.41$.

\subsection{False events}

At Interview 1, 57\% ( $n=43$ ) of the children developed a false memory and $23 \%(n=10)$ of these developed a false memory after having been exposed to guided imagery and context reinstatement techniques. Of these 43 children, no child rejected the false event at Interview 2. At interview 2, 74\% ( $n=56$ ) of the children "remem-

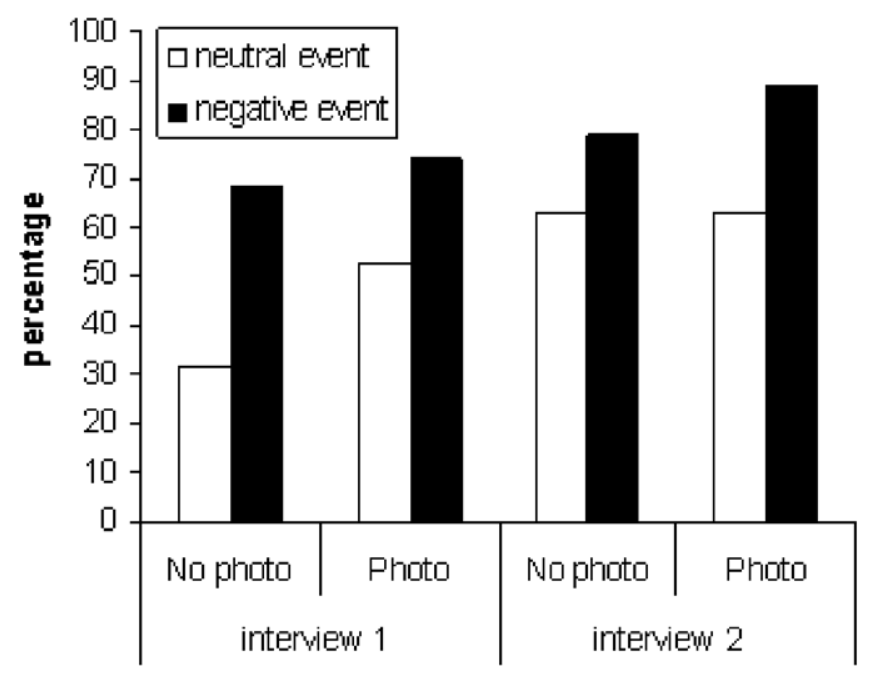

Fig. 1. Percentage of children who developed false memories at Interviews 1 and 2.

bered" the false event, $\chi^{2}(1)=35.37, p<.001$, Cramer's $V=.68$. Five percent $(n=3)$ of these children assented to the false narratives after confrontation with the guided imagery and context reinstatement techniques. The increase of false memories over time is in accordance with the previous studies (e.g., Lindsay et al., 2004; Wade et al., 2002). The following report from Interview 2 is an example of a negative false memory.

Child: I can remember I was doing math. I was sitting next to a boy or a girl, I don't remember. Then I did something, and the boy said: "Why are you copying my work?" But I was only grabbing my pencil. Then he told the teacher and she said: "Why did you cheat?" But I really didn't.

Interviewer: How did you feel?

Child: I was scared because I thought I would get punished.

Fig. 1 shows the percentage of children developing a false memory as a function of the valence of false target events and the absence or presence of photographs.

For data obtained at both interviews, we conducted separate logistic regression analyses, with valence and photographs as predictor variables and the presence/absence of false memories as criterion. We found a non-significant Valence $\times$ Photograph interaction at both interviews (Interview $1: B=.62, S E=.99$, n.s.; Interview 2: $B=-.82, S E=1.15$, n.s.). However, there was a significant main effect of valence at both interviews (Interview $1: B=-1.24$, $S E=.49$, Wald $=6.36, \operatorname{Exp}(B)=.29, p<.05$; Interview 2: $B=-1.14$, $S E=.56$, Wald $=4.16, \operatorname{Exp}(B)=.32, p<.05)$ with the negative narrative eliciting more false memories than the neutral narrative. The main effect of photograph was non-significant at both interviews (Interview 1: $B=.59, S E=.49$, n.s.; Interview $2: B=.29, S E=.54$, n.s.).

\section{Discussion}

The aim of the present study was to examine the role of the valence of false target events in the development of children's false memories. Our study is the first to show that a more ecologically valid false target event with negative connotations is more likely to give rise to a false memory than a neutral false target event, a finding that has obvious implication for the legal domain (see below). This valence effect is in accordance with the recent research suggesting that negative information increases the susceptibility for false memory formation (e.g., Candel, 2006; Nourkova et al., 2004; Porter et al., 1999; Porter et al., 2003). Moreover, our valence 
effect is in agreement with the paradoxical negative emotion hypothesis which states that negative material will not only be recalled well over time, but will also be at risk for the development of false memories (Porter et al., Submitted for publication). Furthermore, we also found that at least in children, the presentation of a recent photographic cue (i.e., a class photograph from the previous year) does not enhance the development of false memories.

As demonstrated by Talmi and colleagues $(2004,2007)$, emotionally negative information and neutral information are organized differently in memory. That is to say, negative information is more interrelated than neutral material. As a result, the presentation of negative information - either true or false - might increase the possibility that other negative materials become activated in memory. This, in turn, could affect the development of a false memory for a negative event. Thus, in the current experiment, the presentation of the negative false narrative about the teacher's accusation of copying off might have activated negative class events that actually did happen to the children, such as getting punished for being boisterous in the classroom. As a by-product of this activation, children might be more willing to believe that the negative false event has also happened to them and this may raise the probability that they develop a false memory for the event. Since neutral information is less interrelated in memory than negative-emotional information, this "chain reaction" will not occur when children are presented with neutral false information.

In terms of fuzzy-trace theory (Brainerd \& Reyna, 1998), one could argue that negative narratives produce relatively more gist memory while neutral narratives produce relatively more verbatim memories. Indeed, recent research suggests that gist representations often include valence (e.g., negative/positive evaluation of an event) and emotions (see for an overview Rivers, Reyna, \& Mills, 2008). Given the fact that gist memories are more stable over time than verbatim memories and given that false memories are almost always gist-based (Reyna, Holliday, \& Marche, 2002), one predicts that negative narratives more readily evoke false memories than neutral narratives. This prediction is borne out by the current data.

Our finding that children are more likely to develop a false memory for a negative event than for a non-negative event seems difficult to reconcile with the studies by Ceci et al. (1994) and Hyman et al. (1995). These authors reported that a negative event elicited fewer or a similar number of false memories as compared with a positive event. However, plausibility of the target events might account for this pattern of findings. In our study, negative and neutral target events were similar in terms of plausibility ${ }^{1}$. Ceci et al. and Hyman et al. did not control for this factor and therefore it might well be the case that their negative target events were less plausible than their positive target, producing the overall null effect of similar levels of false memory. As plausible events are more likely to give rise to false memories than implausible events (Pezdek, Finger, \& Hodge, 1997; Pezdek \& Hodge, 1999; but see Otgaar, Candel, Merckelbach, \& Wade, in press; Strange et al., 2006), controlling this factor in the studies on false memories is crucial.

Our finding also seems to be in contrast with Howe's (2007) study in which children falsely recalled more neutral words than negative words. Howe's study, however, focused on spontaneous

\footnotetext{
${ }^{1}$ One might argue that our valence effect is confounded with using only two target events and that our valence effect is actually a stimulus effect. However, since we controlled for plausibility and script knowledge, our valence effect is not due to other factors. Moreover, Pezdek and colleagues (2006) argued that it is justified to use only two target events in false memory studies, since "it would be methodologically difficult to maintain credibility with the subjects while suggestively introducing multiple false events" (Pezdek et al., 2006, p. 1634). Also, they mentioned that there are important false memory studies which used only one false target event (i.e., lost in a shopping mall, by Loftus \& Pickrell, 1995; put Slime in the teacher's desk, by Lindsay et al., 2004; take a hot air balloon ride, by Wade et al., 2002).
}

false memories using word lists whereas the present study focused on implanted false memories using false narratives. Recently, it has been debated whether both paradigms have the exact same underlying mechanisms (see Pezdek, 2007; Pezdek \& Lam, 2007; Wade et al., 2007). Clearly, this issue warrants further study.

Our false memory rates are higher than those in other false memory studies (e.g., Strange et al., 2006). Note, however, that we combined false narratives and true photographs to implant false memories. Recently, Garry and Wade (2005) found that false narratives produce higher false memory rates than doctored photographs. Furthermore, Lindsay et al. (2004) showed that true photographs evoke higher levels of false memories than studies using doctored photographs. Therefore, it is likely that our combination of false narratives and true photographs engendered higher false memory rates than other false memory studies.

The presentation of a true photograph associated with the false target event did not promote the development of children's false memories. At first sight, this null finding is at odds with Lindsay et al. (2004) who reported that exposing adult participants to a true photograph increased their number of false memories. These discrepant findings might be explained by the children's heightened levels of suggestibility. Specifically, children are more susceptible to suggestive information than adults (for an overview, see Bruck \& Ceci, 1999), which creates ceiling effects in the case of children being exposed to an extra memory cue like a photograph. So, even without being exposed to a true photograph, the number of children with a false memory after two interviews in our study (i.e., 71\%) dramatically exceeded the number of adults with a false memory in Lindsay et al.'s (2004) study (i.e., 27\%). Obviously, many children were influenced by the authoritativeness of the suggested false narrative. As a result, the true photograph did not possess an additional value.

In the legal arena, children are usually interrogated about negative events (Bruck \& Ceci, 1999). Although we admit that our negative target event is a far cry from false memories about childhood sexual abuse, the current study may help to bridge the gap between the psychological laboratory and court cases in which such memories play a crucial role. That is, our study clearly demonstrates that interrogations characterized by suggestive interview techniques are catastrophic in that they increase the likelihood that children come up with "memories" about fictitious events. The argument that is sometimes heard in court - i.e., this memory report must be true because it describes such a horrible event (e.g., Ceci \& Bruck, 1993) - is, as our data show, on shaky grounds.

\section{Acknowledgement}

This study was supported by a grant to Ingrid Candel from the Netherlands Organisation of Scientific Research (NWO), Grant No. 400-05-015.

\section{References}

Brainerd, C. J., \& Reyna, V. F. (1998). Fuzzy-trace theory and children's false memories. Journal of Experimental Child Psychology, 71, 81-129.

Bruck, M., \& Ceci, S. J. (1999). The suggestibility of children's memory. Annual Review of Psychology, 50, 419-439.

Candel, I. (2006). False memories: The role of plausibility and valence. In R. McNally (Chair), Remembering, distorting, and forgetting trauma. Association of Psychological Science Annual Convention, New York.

Ceci, S. J., \& Bruck, M. (1993). The suggestibility of the child witness: A historical review and synthesis. Psychological Bulletin, 113, 403-439.

Ceci, S. J., Loftus, E. F., Leichtman, M. D., \& Bruck, M. (1994). The possible role of source misattributions in creation of false beliefs among preschoolers. International Journal of Clinical and Experimental Hypnosis, 42, 304-320.

Gallo, D. A. (2006). Associative illusions of memory: False memory research in DRM and related tasks. New York: Psychology Press.

Garry, M., \& Gerrie, M. (2005). When photographs create false memories. Current Directions in Psychological Science, 14, 321-325. 
Garry, M., \& Wade, K. A. (2005). Actually, a picture is worth less than 45 words: Narratives produce more false memories than photographs do. Psychonomic Bulletin E Review, 12, 359-366.

Howe, M. L. (2007). Children's emotional false memories. Psychological Science, 18, $856-860$.

Hyman, I. E., Husband, T. H., \& Billings, F. J. (1995). False memories of childhood experiences. Applied Cognitive Psychology, 9, 181-197.

Lindsay, S., Hagen, L., Read, J. D., Wade, K., \& Garry, M. (2004). True photographs and false memories. Psychological Science, 15, 149-154.

Loftus, E. F. (2004). Memories of things unseen. Current Directions in Psychological Science, 13, 145-147.

Loftus, E. F., \& Pickrell, J. E. (1995). The formation of false memories. Psychiatric Annals, 25, 720-725.

Nourkova, V., Bernstein, D. M., \& Loftus, E. F. (2004). Altering traumatic memory Cognition and Emotion, 18, 575-585.

Otgaar, H., Candel, I., Merckelbach, H, \& Wade, K. A. (in press). Abducted by a UFO Prevalence information affects the development of young children's false memories for an implausible event. Applied Cognitive Psychology.

Pezdek, K. (2007). It's just not good science. Consciousness and Cognition, 16, 29-30.

Pezdek, K., Finger, K., \& Hodge, D. (1997). Planting false childhood memories: The role of event plausibility. Psychological Science, 8, 437-441.

Pezdek, K., \& Hodge, D. (1999). Planting false childhood memories in children: The role of event plausibility. Child Development, 70, 887-895.

Pezdek, K., \& Lam, S. (2007). What research paradigms have cognitive psychologists used to study "False memory", and what are the implications of these choices? Consciousness and Cognition, 16, 2-17.

Pollack, S. D., \& Kistler, D. J. (2002). Early experience is associated with the development of categorical representations for facial expressions of emotion. Proceedings of the National Academy of Sciences USA, 99, 9072-9076.

Poole, D. A., Lindsay, D. S., Memon, A., \& Bull, R. (1995). Psychotherapy and the recovery of memories of childhood sexual abuse: U.S. and British practitioners' opinions, practices, and experiences. Journal of Clinical and Consulting Psychology, 63, 426-437.
Porter, S., Bellhouse, S., McDougall, A., ten Brinke, L., \& Wilson, K. A prospective investigation of the vulnerability of positive and negative scenes to the misinformation effect, Submitted for publication.

Porter, S., Spencer, L., \& Birt, A. (2003). Blinded by emotion? Effect of emotionality of a scene on susceptibility to false memories. Canadian Journal of Behavioral Sciences, 35, 165-175.

Porter, S., Taylor, K., \& ten Brinke, L. Memory for media: An investigation of false memories for negatively- and positively-charged public events, Submitted for publication.

Porter, S., Yuille, J. C., \& Lehman, D. R. (1999). The nature of real, implanted, and fabricated memories for emotional childhood event: Implications for he recovered memory debate. Law and Human Behavior, 23, 517-537.

Reyna, V., Holliday, R., \& Marche, T. (2002). Explaining the development of false memories. Developmental Review, 22, 436-489.

Rivers, S. E., Reyna, V. F., \& Mills, B. (2008). Risk taking under the influence: A fuzzy trace theory of emotion in adolescence. Developmental Review, 28, 107-144.

Scoboria, A., Mazzoni, G., Kirsch, I., \& Relyea, M. (2004). Plausibility and belief in autobiographical memory. Applied Cognitive Psychology, 18, 791-807.

Strange, D., Sutherland, R., \& Garry, M. (2006). Event plausibility does not determine children's false memories. Memory, 14, 937-951.

Talmi, D., \& Moscovitsch, M. (2004). Can semantic relatedness explain the enhancement of memory for emotional words? Memory \& Cognition, 32, $742-751$.

Talmi, D., Luk, B., McGarry, L., \& Moscovitch, M. (2007). The contribution of relatedness and distinctiveness to emotionally-enhanced memory. Journal of Memory and Language, 56, 555-574.

Wade, K. A., Garry, M., Read, J. D., \& Lindsay, S. (2002). A picture is worth a thousand lies: Using false photographs to create false childhood memories. Psychonomic Bulletin E Review, 9, 597-603.

Wade, K., Sharman, S., Garry, M., Memon, A., Mazzoni, G., Merckelbach, H., \& Loftus, E. (2007). False claims about false memory research. Consciousness and Cognition, 16, 18-28 